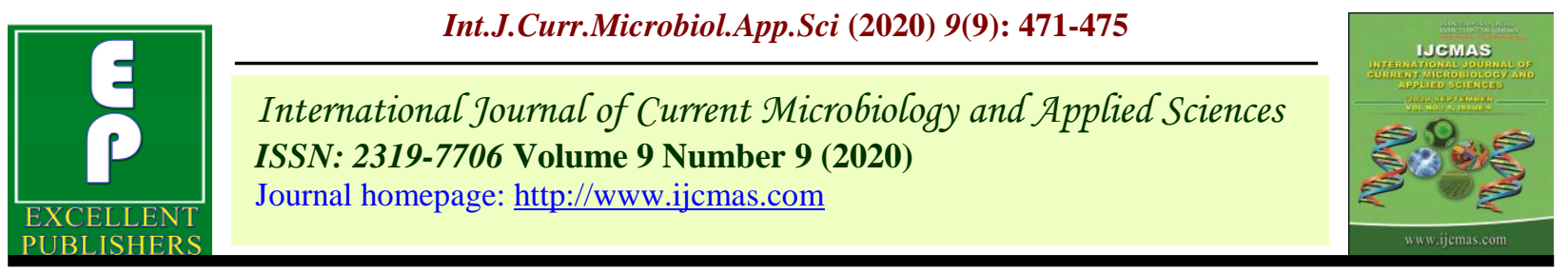

\title{
Studies on Effect of Weed Management Practices on Plant Growth, Root Growth, Yield and its Attributing Traits in Turmeric (Curcuma longa L.)
}

\author{
Kumar Anshuman ${ }^{1 *}$, Alok Kumar ${ }^{1}$, Awadhesh Kumar Singh ${ }^{2}$, \\ Ravikesh Kumar Pal ${ }^{3}$ and Brijesh Kumar Pandey ${ }^{4}$
}

${ }^{1}$ Department of Soil Science \& Agriculture, ${ }^{3}$ Department of Agronomy, Chemistry, NDUAT Kumarganj, Ayodhya, India

${ }^{2}$ Department of Soil Science \& Agriculture, Chemistry, P.G. College, Ghazipur, India

${ }^{4}$ Department of Soil Science \& Agriculture, Chemistry, U.P. College, Varanasi, India

*Corresponding author

\section{A B S T R A C T}

\begin{tabular}{|l|}
\hline Ke y w o r d s \\
$\begin{array}{l}\text { Paddy Straw Mulch, } \\
\text { Turmeric, Root and } \\
\text { Rhizomes }\end{array}$ \\
\hline Article Info \\
\hline $\begin{array}{l}\text { Accepted: } \\
\text { 07 August } 2020 \\
\text { Available Online: } \\
\text { 10 September } 2020\end{array}$ \\
\hline
\end{tabular}

\begin{abstract}
The experiment was conducted with five treatments and four replications in Randomized Block Design (RBD) during Kharif season of 2016-17 at Agronomy Research Farm, N.D. University of Agriculture and Technology, Kumarganj, Ayodhya (U.P.). Five treatments are selected of which two treatments were supplied with $5 \mathrm{t} / \mathrm{ha}$ and $10 \mathrm{t} / \mathrm{ha}$ paddy straw mulch and other three non-mulched viz. four hand weedings alone, herbicide (metribuzin P.E.) with two hand weedings and weedy check. Among all the five treatments maximum plant height $(107.2 \mathrm{~cm})$, number of leaves $(9.0)$, number of tillers $(4.71)$, root length $(35.1 \mathrm{~cm})$, root weight $(25.2 \mathrm{~g})$, root volume $\left(28.4 \mathrm{~cm}^{3}\right)$, number of primary, secondary and tertiary rhizomes $(6.6,15.8$ and 5.1 respectively), weight of mother, primary, secondary, tertiary rhizomes(43.2g, 174.2g, 270.1g, 14.3g respectively) and fresh rhizome yield (32.9 t/ha) observed in the treatment applying paddy straw mulch @ $10 \mathrm{t} / \mathrm{ha}$ followed by paddy straw mulch@5 t/ha.
\end{abstract}

\section{Introduction}

Turmeric (Curcuma longa L.) is a herbaceous plant belonging to family Zingiberaceae and order Scitaminae. It contains appreciable quantities of proteins $(6.3 \%)$, lipids $(5.1 \%)$, minerals $(3.5 \%)$ carbohydrates $(69.4 \%)$ and fibre $(2.6 \%)$. Turmeric is rich in minerals like phosphorus, calcium, iron and vitamin ' $\mathrm{A}$ '. It is one of most valuable spices, known as "Indian saffron" because of its deep yellow orange colour. It is used in diversified form of condiment flavouring agent and colouring agent as principle ingredient in Indian culinary as curry powder. It has anticancer and antiviral action hence, it also find use in drug and cosmetic industry. Traditionally turmeric has been used in India for treatment of variety of human and veterinary ailment, as a natural dyes, as well as preparation of delicious dishes. India is largest producer, consumer and exporter of turmeric in world. India contributes to about $78 \%$ of turmeric production followed by China $8 \%$, Myanmar 
4\%, Nigeria and Bangladesh combindly $6 \%$ of total global production. In India, it is grown over an area of 0.238 million ha with a production and productivity of 1.133 million tonnes and $4.76 \mathrm{t} / \mathrm{ha}$, respectively (Anonymous, 2018).

\section{Materials and Methods}

The experiment was carried out at Agronomy Research Farm, Kumarganj, Ayodhya during Kharif season 2016-17. The experiment was laid out in Randomized Block Design. The soil of experimental was slightly alkaline in reaction $(\mathrm{pH} 8.25)$, low in organic manure $(4.5 \mathrm{~g} / \mathrm{kg})$ and available N (198 kg/ha), medium in available $\mathrm{P}(20.1 \mathrm{~kg} / \mathrm{ha})$, and high available $\mathrm{K}(321 \mathrm{~kg} / \mathrm{ha})$. The turmeric variety 'Narendra Haldi-1'was planted at $45 \times 10 \mathrm{~cm}$ spacing on $24^{\text {th }}$ June 2016. The $100 \%$ recommended dose of nitrogen $(120 \mathrm{~kg} / \mathrm{ha})$ applied uniformly through farm yard manure. There were five treatments and four replications. The details of treatments are given below:

The experimental data analyzed using 'Analysis of Variance technique' in Randomized Block Design. The critical differences at 5 per cent of probability were calculated for testing the significance of difference between any two means where ' $F$ ' test was significant (Snedecor and Cochran, 1967).

\section{Results and Discussion}

\section{Growth parameters}

Among different weed management treatments, mulch treatments viz. paddy straw mulch@5 and 10 t/ha showed significantly tallest plants $(97.2-102.6 \mathrm{~cm})$, more number of leaves per plant (8.40-9.00) and tillers per plant (4.32-4.71) as compared to non-mulched treatments viz. four hand weedings alone and integrated with herbicide (metribuzin) followed by two hand weedings. The results also revealed that growth parameters (plant height, number of leaves and tillers per plant) increased with increasing the rate of mulch from 5 to $10 \mathrm{t} / \mathrm{ha}$. There was no significant variation between four hand weedings alone and integrated with herbicide (metribuzin) followed by two hand weedings. The minimum plant height $(51.5 \mathrm{~cm})$, number of leaves (5.1) and number of tillers (2.43) per plant was recorded in weedy check. This might be due to better weed control under mulching with paddy straw. Manhas et al., (2011) also reported that application of paddy straw mulch @ 9.38 t/ha produced significantly tallest plants and more number of tillers and leaves per plant than application of mulch@6.25 t/ha, which in turn was significantly superior to no mulch. Slow rate of decomposition may be the another reason for higher moisture retention with paddy straw mulch, which could be attributed to better crop growth in terms of plant height, number of tillers, leaf length and width which intercepted more light reported by Kumar et al., (2003). Similar results were also reported by Junior et al., (2005) and Verma and Sarnaik (2006).

\section{Root parameters}

Among various weed management practices, mulching with paddy straw @ 5 and 10 tonnes /ha resulted significantly higher root length (32.40-35.10 cm), more fresh root weight (23.49-25.20g) and root volume (26.10-28.40 $\mathrm{cm}^{3}$ ) per plant as compared to the practices having four hand weedings alone and integrated with herbicide (metribuzin) + two hand weedings. The data also showed that root parameters (root length, root weight and root volume per plant) increased with increasing rate of mulch from 5 to $10 \mathrm{t} / \mathrm{ha}$ but increase was non-significant. Similarly, there was no significant variation between four 
hand weedings alone and integrated with herbicide (metribuzin) along with two hand weedings. The weedy check treatment showed minimum root length $(18.30 \mathrm{~cm})$, fresh root weight $(8.91 \mathrm{~g})$ and root volume $\left(9.90 \mathrm{~cm}^{3}\right)$ per plant. Chaudhary and Kumar (2014) also observed the difference between the placed mulch and without mulch and reported that all the root parameters were higher with mulch treatment.

Table.1 Treatment details and symbols used

\begin{tabular}{|c|l|c|}
\hline Symbol & \multicolumn{1}{|c|}{ Details } & Short form \\
\hline $\mathbf{T}_{\mathbf{1}}$ & Paddy straw mulch @ 5 t/ha & $5 \mathrm{t} \mathrm{M}$ \\
\hline $\mathbf{T}_{\mathbf{2}}$ & Paddy straw mulch @ 10 t/ha & $10 \mathrm{t} \mathrm{M}$ \\
\hline $\mathbf{T}_{\mathbf{3}}$ & Hand weedings at 30,60,90 and 120 days after planting (DAP) & $4 \mathrm{HW}$ \\
\hline $\mathbf{T}_{\mathbf{4}}$ & $\begin{array}{l}\text { Herbicide (Metribuzine) @ 750gm/ha followed by two hand weedings } \\
\text { on 45 and 75 days after planting (DAP) }\end{array}$ & Herb.+2 HW \\
\hline $\mathbf{T}_{\mathbf{5}}$ & Weedycheck & $\mathrm{WC}$ \\
\hline
\end{tabular}

Table.2 Effect of weed management practices on plant growth and root growth of turmeric

\begin{tabular}{|c|c|c|c|c|c|c|}
\hline Treatment & $\begin{array}{c}\text { Plant height } \\
\text { (cm) at } 180 \\
\text { DAP }\end{array}$ & $\begin{array}{l}\text { Number of } \\
\text { leaves/plant } \\
\text { at } 90 \text { DAP }\end{array}$ & $\begin{array}{l}\text { Number of } \\
\text { tillers/plant } \\
\text { at } 150 \text { DAP }\end{array}$ & $\begin{array}{c}\text { Root } \\
\text { length }(\mathrm{cm})\end{array}$ & $\begin{array}{c}\text { Root } \\
\text { weight }(g)\end{array}$ & $\begin{array}{c}\text { Root } \\
\text { volume }\left(\mathrm{cm}^{3}\right)\end{array}$ \\
\hline $\mathrm{T}_{1}: 5 \mathrm{tM}$ & 97.2 & 8.4 & 4.32 & 32.40 & 23.49 & 26.10 \\
\hline$T_{2} 10 t M$ & 102.6 & 9.0 & 4.71 & 35.10 & 25.20 & 28.40 \\
\hline $\mathrm{T}_{3}: 4 \mathrm{HW}$ & 87.3 & 6.7 & 3.72 & 27.60 & 20.43 & 22.20 \\
\hline$T_{4}:$ Herb.+ 2 HW & 84.4 & 6.3 & 3.37 & 25.80 & 18.72 & 19.80 \\
\hline $\mathrm{T}_{5}: \mathrm{WC}$ & 51.5 & 5.1 & 2.43 & 18.30 & 8.91 & 9.90 \\
\hline SEm \pm & 2.83 & 0.214 & 0.295 & 1.09 & 0.79 & 0.85 \\
\hline $\mathrm{CD}(\mathrm{P}=0.05)$ & 8.73 & 0.66 & 0.91 & 3.36 & 2.43 & 2.61 \\
\hline
\end{tabular}

Table.3 Effect of weed management practices on number, weight of rhizome and yield of turmeric

\begin{tabular}{|c|c|c|c|c|c|c|c|c|}
\hline \multirow[t]{2}{*}{ Treatment } & \multicolumn{3}{|c|}{ Number of rhizomes per plant } & \multicolumn{4}{|c|}{ Weight of rhizomes per plant } & \multirow{2}{*}{$\begin{array}{c}\text { Fresh } \\
\text { rhizome } \\
\text { yield }(t / h a)\end{array}$} \\
\hline & Primary & Secondary & Tertiary & Mother & Primary & Secondary & Tertiary & \\
\hline $\mathrm{T}_{1}: 5 \mathrm{t} \mathrm{M}$ & 6.3 & 14.7 & 4.7 & 38.5 & 159.1 & 252.3 & 12.2 & 28.3 \\
\hline$T_{2} 10$ tM & 6.6 & 15.8 & 5.1 & 43.2 & 174.2 & 270.1 & 14.3 & 32.9 \\
\hline $\mathrm{T}_{3}: 4 \mathrm{HW}$ & 5.8 & 13.2 & 3.6 & 33.3 & 136.2 & 223.1 & 9.1 & 24.4 \\
\hline $\begin{array}{l}T_{4}: \text { Herb.+ } 2 \\
\text { HW }\end{array}$ & 5.6 & 12.6 & 3.3 & 30.6 & 128.3 & 209.4 & 8.3 & 22.3 \\
\hline $\mathrm{T}_{5}: \mathrm{WC}$ & 3.3 & 8.3 & 1.5 & 20.4 & 81.2 & 117.1 & 3.2 & 14.6 \\
\hline SEm \pm & 0.136 & 0.438 & 0.165 & 1.36 & 6.04 & 7.89 & 0.39 & 1.24 \\
\hline $\mathrm{CD}(\mathrm{P}=\mathbf{0 . 0 5})$ & 0.42 & 1.35 & 0.51 & 4.2 & 18.6 & 24.3 & 1.2 & 3.86 \\
\hline
\end{tabular}


The higher values of root parameters (root depth, weight and density) in mulch treatments might be due to loose soil and sufficient available moisture, as well as more availability of space and nutrients due to lower weed density. Olfati et al., (2008) also reported plants grown with organic mulches resulted higher total yield, root weight, root length, and root density than no mulch. The organic mulches showed better root density possibly due to high moisture retention during initial growth of crop. Kumar et al., (2014) also observed significantly longer roots in mulched plots.

\section{Yield attributes}

Application of paddy straw @ 5 and 10 t/ha resulted higher weight of mother rhizomes (38.5-43.2 g), primary rhizome (159.1-174.2 g), secondary rhizome (252.3-270.1 g), and tertiary rhizome (12.2-14.3 g) as well as total weight (462.1-501.8 g) of rhizomes as compared to other weed management practices viz. four hand weedings alone and integrated with herbicide (metribuzin) + two hand weedings. The reduction in the level of mulch (from 10 to 5 t/ha) resulted significant decrease in the weight of mother rhizome and total weight of rhizomes. Mulching with paddy straw @ 5 and 10 t/ha enhanced weight of mother rhizomes by 15.6 and $29.7 \%$ primary by 16.9 and $27.9 \%$, secondary by 13.0 and $21.7 \%$ and tertiary by 33.3 and $55.5 \%$ and overall total weight of rhizomes per plant by 15.0 and $24.8 \%$, respectively, over the weed management practice of hand weedings alone.

Similarly, the application of mulch @ 5 and 10 $\mathrm{t} / \mathrm{ha}$ increased number of primary rhizome (6.30-6.60), secondary rhizome (14.70-15.80) and tertiary rhizome (4.70-5.10) rhizomes per plant as compared to hand weedings alone. Mulching with 5 and 10 t/ha also enhanced number of primary rhizome by 8.6 and $13.7 \%$, secondary by 11.3 and $19.6 \%$ and tertiary by 30 and $41.6 \%$ per plant, respectively over conventional four hand weedings alone. The results also revealed that weight and number of rhizomes increased with increasing the level of mulch from 5 to $10 \mathrm{t} / \mathrm{ha}$. The minimum weight of mother (20.4 g), primary (81.2 g), secondary $(117.1 \mathrm{~g})$, tertiary $(3.2 \mathrm{~g})$ rhizomes and total weight $(221.9 \mathrm{~g})$ of rhizomes per plant as well as minimum number of primary rhizome (3.3), secondary rhizome (8.3) and tertiary (1.5) rhizomes per plant were recorded in the weedy check. Manhas et al., (2011) reported that effective weed control provided more number of tillers and more leaves which might be the reason for increase in number and weight of rhizomes per plant. The increase in number and weight of rhizomes per plant with mulch and FYM might be due to better weed control, increase nutrient availability and water availability to crop Kumar et al., (2017) also reported an increase in number and weight of rhizomes per plant due to mulch application.

\section{Yield}

Among the different weed management practices, mulching with paddy straw @ 5 and 10 tonnes/ha provided significantly higher rhizome yields (28.3 - 32.9 t/ha) as compared to non-mulched weed management practices viz. having four hand weedings alone and integrated with herbicide (metribuzin P.E.) along with two hand weedings. On the other hand, mulching with 5 and 10 t/ha paddy straw enhanced rhizome yield by $16.3 \%$ and $35.3 \%$, respectively, over the conventional weed management practice of four hand weedings alone. The results revealed that yield of rhizome significantly increased with increased level of mulch from 5 to $10 \mathrm{t} / \mathrm{ha}$. There was no significant variation in yield of rhizomes between treatments having four hand weedings alone and integrated with herbicide (metribuzin P.E.) with two hand weedings. The minimum rhizome yield (14.6 t/ha) was recorded in treatment of weedy check. Gill et al., (1999) reported that application of straw mulch (6 t/ha) also increased fresh rhizome yield of turmeric significantly over no mulch. The higher rhizome yield with straw mulch was due to the improved growth characters and reduced competition by weeds. The higher yield realization in mulched plots apparently resulted 
from quick emergence because of favourable moisture and temperature conditions reported by Kaur and Brar (2016). Kumar et al., (2017) also concluded that paddy straw mulching (6.25 $\mathrm{t} / \mathrm{ha}$ ) proved beneficial in turmeric cultivation as it enhanced the growth, rhizome yield and quality. Besides, it has also the potential to conserve the soil moisture and reduce the weed infestation.

In conclusion on the basis of results, it may be concluded that the application of paddy straw mulch (@5 and 10) t/ha was found more effective to control weeds which ultimately provided better plant growth and higher yield of turmeric.

\section{References}

Anonymous (2018). Horticulture Database, National Horticulture Board, Ministry of Agriculture and Farmers Welfare, Government of India, Gurugram, Haryana, India.

Chaudhary, V.K. and Kumar, P.S. (2014). Influence of mulching on productivity, root growth and weed dynamics of maize (Zea mays) based cropping systems. Indian Journal of Agronomy 9(3):364370.

Gill, B.S., Randhawa, R.S., Randhawa, G.S. and Singh, J. (1999). Response of turmeric to nitrogen in relation to application of FYM and straw mulch. Journal of Spices and Aromatic Crop, 8(2): 211-214.

Junior, M.A., Borella, J.C., Franca, S.C. and Masea, M.G. (2005). Revista Brasileirade-Plantas Medicinais 8(1): 30-40.

Kaur, A. and Brar, A.S. (2016). Influence of mulching and irrigation scheduling on productivity and water use of turmeric in north western India. Irrigation Science 34: 261-269.

Kumar, D., Singh, R., Gadekar, H. and Patnaik, U.S. (2003). Effect of different mulches on moisture conservation and productivity of rainfed turmeric. Indian Journal of Soil Conservation, 31(1): 4144.

Kumar, R., Sood, S., Sharma, S., Kasna, R.C., Pathania, V.L., Singh, B. and Singh, R.D. (2014). Effect of plant spacing and organic mulch on growth, yield and quality of natural sweetner plant stevia and soil fertility in western Himalaya. International Journal of Plant Production, 8(3):311-334.

Kumar, R., Kumar, J., Brar, A.S., Walia, S.S. and Gill, B.S. (2017). Effect of straw mulch and integrated nitrogen management on yield and quality of turmeric under North Indian plains. Indian J. Hort. 74(2): 240-244.

Manhas, S.S., Gill, B.S., Khajuria, V. and Kumar, S. (2011). Effect of planting material, mulch and farm yard manure on weed density, rhizome yield and quality of turmeric. Indian journal of Agronomy, 56(4): 393-399.

Olfati, J.A., Peyvast, G. and Rad, Z. (2008). Organic mulching on carrot yield and quality. International journal of vegetable science 14(4): 363 -368.

Verma, A. and Sarnaik, D.A. (2006). Effect of different type of mulches on growth and yield of turmeric. International Journal of Agril. Science, 2: 425-426.

\section{How to cite this article:}

Kumar Anshuman, Alok Kumar, Awadhesh Kumar Singh, Ravikesh Kumar Pal and Brijesh Kumar Pandey. 2020. Studies on Effect of Weed Management Practices on Plant Growth, Root Growth, Yield and its Attributing Traits in Turmeric (Curcuma longa L.). Int.J.Curr.Microbiol.App.Sci. 9(09): 471-475. doi: https://doi.org/10.20546/ijcmas.2020.909.060 